\title{
Hydrogeologic Reconnaissance of the Mekong Delta in South Vietnam and Cambodia
}

By HENRY R. ANDERSON

CONTRIBUTIONS TO THE HYDROLOGY OF ASIA AND OCEANIA

GEOLOGICAL SURVEY WATER-SUPPLY PAPER 1608-R

Prepared in cooperation with the Governments of South Vietnam and Cambodia under the auspices of the United States Agency for International Development

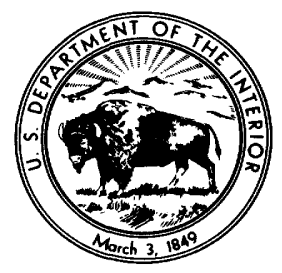




\title{
UNITED STATES DEPARTMENT OF THE INTERIOR
}

\author{
CECIL D. ANDRUS, Secretary
}

GEOLOGICAL SURVEY

H. William Menard, Director

Library of Congress Cataloging in Publication Data

Anderson, Henry R. 1936-

Hydrogeologic reconnaissance of the Mekong Delta in South Vietnam and Cambodia.

(Contributions to the hydrology of Asia and Oceania)

(Geological Survey Water-Supply Paper 1608-R)

Bibliography: p. 24

Supt. of Docs. no.: I 19.13:1608-R

1. Water, Underground-Mekong River-Delta.

I. Title. II. Series. III. Series: United States Geological Survey Water-Supply Paper I608-R.

TC801.U2 [GB1159.V52] 553'.7'0973s [553'.79'09597] 76-608284

For sale by the Superintendent of Documents, U.S. Government Printing Office

Washington, D.C. 20402

Stock Number 024-001-03095-1 


\section{CONTENTS}

Page

Abstract $\ldots \ldots \ldots \ldots \ldots \ldots \ldots \ldots \ldots \ldots \ldots \ldots \ldots \ldots \ldots \ldots \ldots \ldots \ldots \ldots \ldots \ldots, \quad \mathbf{R} 1$

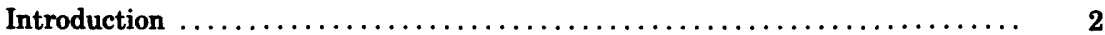

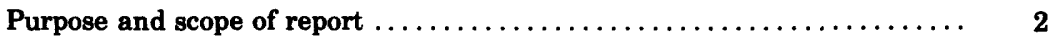

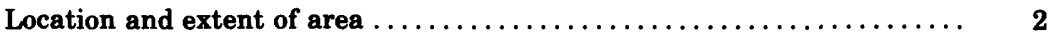

Previous investigations $\ldots \ldots \ldots \ldots \ldots \ldots \ldots \ldots \ldots \ldots \ldots \ldots \ldots \ldots, \quad 3$

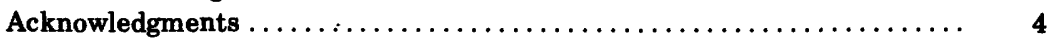

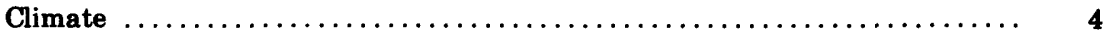

Hydrologic features of the Mekong Delta region $\ldots \ldots \ldots \ldots \ldots \ldots \ldots \ldots \ldots, 5$

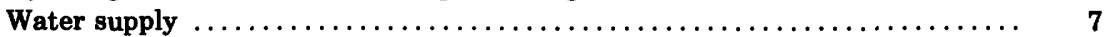

Surface water $\ldots \ldots \ldots \ldots \ldots \ldots \ldots \ldots \ldots \ldots \ldots \ldots \ldots \ldots \ldots \ldots \ldots, 7$

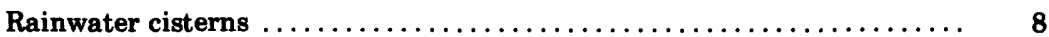

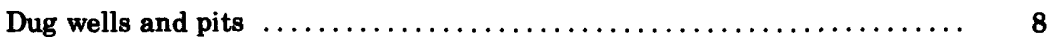

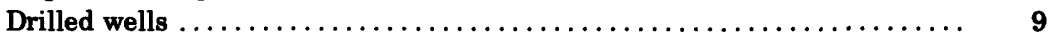

Geologic setting of the Mekong Delta region ........................ 9

Ground water in Quaternary alluvium of the Mekong Delta ............ $\mathbf{1 2}$

Holocene Alluvium $\ldots \ldots \ldots \ldots \ldots \ldots \ldots \ldots \ldots \ldots \ldots \ldots, 13$

Shallow freshwater in ancient beach and dune ridges $\ldots \ldots \ldots \ldots \ldots .14$

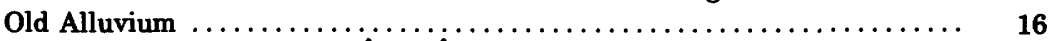

Area southwest of the Sông Hậu Giang including the Ca Mau Peninsula 16

Bac Lieu 100-metre aquifer ....................... 16

Bai Xau 450-metre aquifer ........................ 18

Interfluve between the Sông Hậu Giang and the Mekong River ..... 18

Area north of the Song My Tho and the Mekong River ........... 19

Saigon Tri-Partite sands ......................... 19

Long An 200-metre aquifer ................. 21

Aquifer in outcrop area of Old Alluvium northwest of Saigon .... 22

Conclusions $\ldots \ldots \ldots \ldots \ldots \ldots \ldots \ldots \ldots \ldots \ldots \ldots \ldots \ldots \ldots \ldots \ldots \ldots \ldots \ldots, \quad 23$

References $\ldots \ldots \ldots \ldots \ldots \ldots \ldots \ldots \ldots \ldots \ldots \ldots \ldots \ldots \ldots \ldots \ldots \ldots \ldots \ldots, \quad 24$

\section{ILLUSTRATIONS}

[Plates are in pocket]

Plate 1. Map showing hydrologic features of the Mekong Delta, South Vietnam and Cambodia.

2. Map showing elevation of the regional water table, Mekong Delta region, South Vietnam and Cambodia.

3. Hydrogeologic sections, Mekong Delta region, South Vietnam.

A. Ca Mau Peninsula from Sông Ông Đốc to Tru'òng Khánh.

B. Cái Nu'óc to Vinh Long.

C. Outer fringe of the Mekong Delta from Bai Xàu to Biên Hòa.

D. Mỹ Tho to Nha Bè. 
FIGURE 1. Graph showing average monthly rainfall at Khánh Hu'ng (Soc

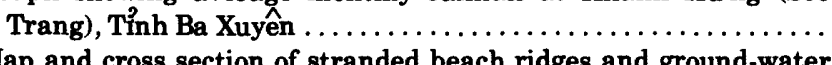
2. Map and cross section of stranded beach ridges and ground-water lenses at $\mathrm{Ba}$ Tri

3. Graphs showing fluctuation of water levels in the Tân Tho'i Nhút (Ton Son Nhut) observation well and rainfall at Saigon ...... 


\title{
HYDROGEOLOGIC RECONNAISSANCE OF THE MEKONG DELTA IN SOUTH VIETNAM AND CAMBODIA
}

\author{
By HenRy R. ANDERSON
}

\begin{abstract}
The present report describes the results of a hydrogeologic reconnaissance in the Mekong Delta region by the writer, a hydrogeologist of the U.S. Geological Survey, while on assignment as an adviser to the Vietnamese Directorate of Water Supply from October 1968 to April 1970 under the auspices of the U.S. Agency for International Development. The delta of the Mekong River, comprising an area of about 70,000 square kilometres in South Vietnam and Cambodia, is an almost featureless plain rising gradually from sea level to about 5 metres above sea level at its apex 300 kilometres inland.

Most of the shallow ground water in the Holocene Alluvium of the delta in Vietnam is brackish or saline down to depths of 50 to 100 metres. Moreover, in the Đông Tháp Mu'o'i (Plain of Reeds) the shallow ground water is alum-bearing. Locally, however, perched bodies of fresh ground water occur in ancient beach and dune ridges and are tapped by shallow dug wells or pits for village and domestic water supply. The Old Alluvium beneath the lower delta contains freshwater in some areas, notably in the Ca Mau Peninsula and adjacent areas, in the viciniy of Bau Xau near Saigon, and in the Tinh Long An area. Elsewhere in the lower delta both the Holocene and Old Alluvium may contain brackish or saline water from the land surface to depths of as much as 568 metres, as for example in Tinh Vinh Bính. Ground water in the outcrop area of Old Alluvium northwest of Saigon is generally fresh and potable, but high iron and low $\mathrm{pH}$ are locally troublesome.

Although considerable exploratory drilling for ground water down to depths of as much as 568 metres has already been completed, large areas of the delta remain yet to be explored before full development of the ground-water potential can be realized. With careful development and controlled management to avoid saltwater contamination, however, it is estimated that freshwater aquifers could provide approximately 80 percent of existing needs for village and small municipal supplies in the delta.
\end{abstract}




\section{INTRODUCTION}

\section{PURPOSE AND SCOPE OF REPORT}

The present report is based on field studies and data collected by the writer, a hydrogeologist of the U.S. Geological Survey (USGS), while on assignment from October 1968 to April 1970 as an advisor to the Vietnamese Directorate of Water Supply under the auspices of the U.S. Agency for International Development (US AID). During this assignment the writer provided guidance on problems of ground-water development for village and small municipal water supplies and on exploratory drilling, chiefly in the Mekong Delta.

The report describes the general hydrogeology of the Mekong Delta and the adjacent region in South Vietnam and Cambodia, summarizes the results of exploratory wells put down in the delta to depths of 50 to $568 \mathrm{~m}$ (metres), and the general availability of ground water for rural and municipal water supply in the 15-tinh (province) region of the delta in South Vietnam.

The ground-water conditions in five areas of the Mekong Delta are described as follows: the area southwest of Sông Hậu Giang, (Bassac River) including the $\mathrm{Ca}$ Mau Peninsula; the interfluve between the Sông Hậu Giang and the Mekong River; the area north of the Mekong and Song Mỹ Tho; and the outcrop area of Old Alluvium, all in South Vietnam. Included in the report are descriptions of the hydrologic features and geologic setting of the Mekong Delta and adjacent region, the aquifers in the deltaic alluvial complex, and the quality and quantity of water available from individual aquifers.

\section{LOCATION AND EXTENT OF AREA}

The delta of the Mekong River and its principal tributary, the Sông Hậu Giang, covers approximately $70,000 \mathrm{~km}^{2}$ (square kilometres) in the Republics of Vietnam (South Vietnam) and the Khmer Republic (Cambodia) in southeast Asia between lat $8^{\circ} 30^{\prime}$ and $11^{\circ} \mathrm{N}$ and long $104^{\circ} 30^{\prime}$ and $107^{\circ} \mathrm{E}$. The vast alluvial plain, which constitutes the delta, attains a length of some $400 \mathrm{~km}$ along its outer or seaward periphery in South Vietnam and extends northwestward some $300 \mathrm{~km}$ to an apex in Cambodia near Phnom Penh. Except for isolated bedrock hills, notably the Seven Mountains, the deltaic plain is almost featureless and rises imperceptibly from sea level to about $5 \mathrm{~m}$ at the delta apex. Near the coast, however, stranded beach ridges locally rise to elevations of 5 to $8 \mathrm{~m}$ above sea level. The hills and uplands bordering the deltaic plain, however, rise to elevations of 100 to $900 \mathrm{~m}$ or more above sea level. 


\section{PREVIOUS INVESTIGATIONS}

Some of the earliest most widely used water-resources studies of the Mekong Delta were surface-water salinity maps produced by the French in 1939-40. These show the extent of sea-water intrusion into the delta waterways for each month of the year.

Ground-water investigations in the delta of South Vietnam are more recent and for the most part of local scope. Although well-drilling activities by the Layne International Co. date back to 1932, the first attempts at describing regional aspects of ground-water occurrence in the delta began about 1960. As a result of saltwater intrusion into the aquifers near Saigon, several ground-water studies were carried out by consultants including Leggette, Brashears and Graham, 1960; Roman Karpoff, 1959; John Charles, 1959; and R. G. Kazmann, 1959. The latter two studies were made for International Water Corp. of Layne Wells. These studies pointed out that the well fields particularly in the Cho Lon (Cholon) district of the city were being contaminated by saltwater intrusion and that the safe yield from the Saigon "Tripartite" sands of the Saigon area was being exceeded. Subsequently, an alternative source of supply was obtained from a surface-water intake on the Sông Đông Nai about $20 \mathrm{~km}$ north of Saigon.

Somewhat later during 1964-65 the late W. C. Rasmussen, a USGS hydrogeologist then assigned to the Rural Water Supply Task Force of US AID/Vietnam, carried out studies of ground-water problems in several parts of the Mekong Delta, but these covered areas of somewhat limited extent. Rasmussen, however, made significant contributions in a quality of water evaluation of the shallow ground water in the Đông Tháp Mu'o'i and in definition of a number of aquifers in the delta. Prior to his assignment to Vietnam, Rasmussen had collected data on more than 1,000 wells and had completed a preliminary evaluation of ground-water conditions in Cambodia (Rasmussen and Bradford, 1975). The results of this work were also used in the present investigation.

Other recent ground-water studies include work by US AID groundwater advisors Jesse F. Cooper during 1965 and R. L. Gamer during 1966-68, both of whom contributed a great deal to the knowledge of the hydrogeology of Vietnam, particularly north of the Mekong Delta in the Coastal Lowlands and Central Highlands regions. H. F. Haworth, who was the US AID ground-water advisor in charge of the Rural Water Supply Program during 1966-68, reported on the total drilling effort prior to 1966 in Vietnam. In the period 1964-66 some 31 of 176 wells drilled in Vietnam were put down in the Mekong Delta to depths ranging from 90 to $291 \mathrm{~m}$. In addition a total of 227 temporary low-yield hydrojet wells were put down, many of these also in the delta. 
Victor H. Pham, Vietnamese engineering geologist, worked with all the US AID ground-water advisors during the 1960's and early 1970's. He completed independently a number of valuable studies particularly on the salinity of surface and ground water in the delta of Vietnam. In addition, he carried out borehole geophysical studies in test wells to define freshwater and saltwater zones in the alluvial deposits of the delta.

\section{ACKNOWLEDGMENTS}

The writer wishes to express his appreciation to a number of individuals who were working in South Vietnam at the time of his assignment and who contributed valuable data and interpretations utilized in this report. Among these were the late W. C. Rasmussen, John Burgh, James Rammelcamp, and Dao Duy, all of William C. Rasmussen and Associates. Assistance also was given by Eugene D. Michaels of Control Data Corporation, then attached to the Military Assistance Command Science Advisor's (MACSA) office in Vietnam. Jesse F. Cooper, formerly with US AID in Laos and South Vietnam and more recently with International Water Corporation of Layne Wells, Saigon, volunteered much useful information with respect to ground-water conditions in the Mekong Delta.

Additionally, a large amount of well data was obtained from contractor and government drillers, in particular Lester Maupin, chief US AID drilling advisor, James McClellan, Earl Nelson, Bus Parmenter, US AID drilling advisors in the Mekong Delta, Jodee Hembree, Asia Wells driller, Messrs. Khiem and Thanh of Vietnamese Rural Water Supply, and Messrs. Hanh and Tho of the Vietnamese Directorate of Water Supply.

Direct assistance was given in the field collection of data for this report by Nguyen Van Re, field assistant, Thrinh Van Phoc, geologist, and Victor H. Pham, engineering geologist, all Vietnamese in the employ of US AID.

The work was conducted under the general supervision of George D. Reasonover, Ralph Bird, Robert C. Small, Jack R. Snead, and James G. Casanos, who at various times served as chiefs of the Water Resources Section of the Engineering Division of US AID/Vietnam.

\section{CLIMATE}

The climate in the Mekong Delta region is dominated by seasonal winds or monsoons. The southwest monsoon arrives about May bringing with it heavy cloud cover and thundershowers. The southwest monsoon usually continues in force until November, with rains occurring almost daily during this season. Moisture is picked up by the southwest winds from the warm tropical waters of the Gulf of Thai- 
land (Gulf of Siam) and then is released over the delta region upon rising, cooling, and moving toward the highlands to the north. Rainfall during the southwest monsoon is usually about $1,750 \mathrm{~mm}$ (millimetres) a year in the delta region but increases to as much as $3,500 \mathrm{~mm}$ a year in the Central Highlands of South Vietnam near Pleiku. In the Mekong Delta the precipitation is more or less evenly distributed from month to month during the rainy season (fig. 1). From May to October the monthly average is about $250 \mathrm{~mm}$. Temperatures are everywhere high in the delta region during this season and usually are above $26^{\circ} \mathrm{C}$.

During October the region experiences a period of transition in which a change occurs from the warm moist tropical winds of the southwest monsoon to the cooler and drier winds of the northeast monsoon which then prevail until April. During the period, November to March, the weather in the delta region is generally dry and relatively cool. Beginning in March, however, and until the onset of the southwest monsoon in May, the delta region experiences increasingly humid and very hot weather.

\section{HYDROLOGIC FEATURES OF THE MEKONG DELTA REGION}

The hydrologic regimen of the Mekong Delta and the adjacent region is dominated by the Mekong River and its sister, the Song Hạu Giang, the chief contributors of freshwater to the delta. The

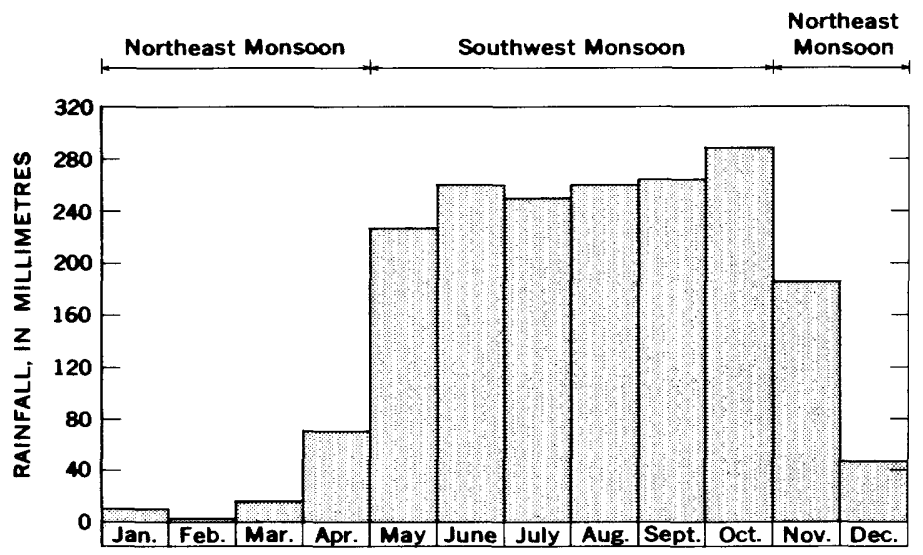

\begin{tabular}{|c|c|c|c|c|c|c|c|c|c|c|c|c|c|}
\hline Average & 8.8 & 2.1 & 14.6 & 68.0 & 223 & 249 & 246 & 263 & 264 & 285 & 174 & 42.3 & $1845 \mathrm{~mm}$ \\
\hline Record High & 61 & 33 & 197 & 326 & 478 & 537 & 516 & 502 & 528 & 641 & 675 & 156 & $2611(1929)$ \\
Record Low & 0 & 0 & 0 & 0 & 25 & 142 & 73 & 101 & 121 & 102 & 0 & 0 & $1160(1957)$ \\
\hline
\end{tabular}

For period of record 1907-12, 1914-30, 1934-44, 1949-67

FiguRE 1. - Average monthly rainfall at Khánh Hu'ng (Soc Trang), Tỉnh Ba Xuyên. 
Mekong, Asia's third longest river, rises at an elevation of more than 4,800 $\mathrm{m}$ in the snowy Tanglha Range of eastern Tibet, sweeps down through $4,185 \mathrm{~km}$ of mountain gorges and valleys from China, Burma, and Thailand into Laos, then flows through the lowlands of Cambodia and South Vietnam, and finally empties through deltaic distributaries into the South China Sea. Annually, the Mekong system discharges a total of about $493 \times 10^{9} \mathrm{~m}^{3}$ of freshwater through the delta.

Despite the Mekong's great length and drainage area, estimated at $795,000 \mathrm{~km}^{2}$, the flow fluctuates widely from season to season. In August 1965, for example, usually the wettest month of the year, the flow at Phnom Penh reached a peak of $45,710 \mathrm{~m}^{3} / \mathrm{s}$ (cubic metres per second) or about two-thirds of the peak flow of the Mississippi when in flood. In contrast in April 1966, usually the driest month, the flow diminished to a low of $1,850 \mathrm{~m}^{3} / \mathrm{s}$. Overall, the mean annual flow of the Mekong River is about $2,860 \mathrm{~m}^{3} / \mathrm{s}$. In terms of river stage the range in level from wet to dry season is about $10 \mathrm{~m}$ at Phnom Penh in Cambodia and about $5 \mathrm{~m}$ near Châu Phú (Chau Doc) in South Vietnam.

The Sông Hậu Giang is a continuation of the Tônlé Basăk which drains the Tonle Sap (Grand Lac), a lake in Cambodia. During the rainy season the overflow from the Mekong backs up the Tônlé Sap increasing the lake to an area of some $10,000 \mathrm{~km}^{2}$ and raising its water level to as much as $11 \mathrm{~m}$ above sea level. This area is approximately three times greater and its water level is some $9 \mathrm{~m}$ higher than the dry-season counterpart. At Châu Phú, the Sông Hậu Giang carries a flow of about one-third that of the Mekong near the same station. The two rivers, however, are interconnected farther downstream and interchange between them tends to equalize the flows. For example, measurements in September 1943 indicated flows of the Mekong River and the Sông Hậu Giang near Châu Phú of 740 and $230 \mathrm{~m}^{3} / \mathrm{s}$, respectively. Downstream of the connecting branch near Cao Lanh, however, the flows were almost equal, 520 and $500 \mathrm{~m}^{3} / \mathrm{s}$, respectively. Thus, by transfer through this branch the flow of the Mekong River was reduced by one third and the flow of the Sông Hâu Giang was doubled.

During the high-water season (August-November) about half the delta is inundated by overflow of the Mekong River and the Sông Hậu Giang. A great part of this water floods a large infertile wasteland commonly referred to as the Đông Tháp Mu'o'i. In this area as a result of the seasonal flooding and drying, the soils have become saturated with aluminum and iron salts, which are toxic to most crops. Natural drainage of the Đông Tháp Mu'o''i is very poor. The area is so low (elevation 1 to $2 \mathrm{~m}$ ) that sometimes tidal incursions of saltwater during the low-water season reach inland as far as Môc Hóa near the Cambodian border. The main stream draining this area is the 
Sông Vàm Cỏ Tây (west Vaico River, formerly Vaico Occidental) which has headwaters just inside Cambodia. The Sông Vàm Co Đông (east Vaico River, formerly Vaico Oriental) a twin tributary, flows along the northern edge of the Parrots Beak with headwaters also in Cambodia. Complicating the natural stream system of the delta is a closely integrated man-made network of approximately $4,000 \mathrm{~km}$ of canals and inland waterways. These are subject to tidal incursions of brackish or salty water from the South China Sea which may extend far inland during the low-water season (February-April) on the Mekong and Sông Hậu Giang.

\section{WATER SUPPLY}

Except for the inland part of the Mekong Delta, the primary water problem for the inhabitants has been the availability of dependable year-round sources of freshwater for livestock, domestic, and municipal requirements. More than half the delta in South Vietnam is subject to incursion through streams and man-made waterways of brackish or salty tidal waters from the South China Sea during the dry season (November-April); about one quarter of the delta is similarly affected even during the wet season (May-November) (plate 1). Consequently, because surface water is not always a dependable source of freshwater, cultivators and townsmen living in the outer (seaward) sector of the delta have had to rely on ground water as a source of potable supply. Initially, water was drawn from shallow wells tapping lenses of freshwater contained in sands of abandoned beach ridges or in levees in the delta. More recently, with the introduction of deep drilling by both private contractors and government agencies, it has been possible to identify deeper freshwater aquifers in several favored areas of the delta.

\section{SURFACE WATER}

Traditionally, the chief source of supply of freshwater for the inner (inland) sector of the delta is from surface watercourses and canals. Surface-water treatment plants built by the French, are still in operation at Châu Phú, Long Xuyên, and Cân Tho' on the Sông Hậu Giang and at Sa Đéc (Sadec), Viñh Long, and Mỹ Tho on the Mekong River. The surface-water treatment plants, however, require sand-filtration units which are expensive to build and difficult to maintain in Vietnam. Consequently, where fresh ground water is available, wells offer more economic sources of water supply for village and small municipal requirements.

In certain areas of the outer (seaward) sector of the delta where both ground water and surface water (at least seasonally) is brackish or salty, various forms of above-ground storage are utilized. A typical 
case in point is the city of Gò Công located about $60 \mathrm{~km}$ south of Saigon in an area of salt marshes. Here test drilling by the French in the 1930's and more recent drilling by the Government of South Vietnam (GVN) and US AID in 1969 failed to discover any deep-lying freshwater aquifers down to a depth of $518 \mathrm{~m}$. Furthermore, the area lacks abandoned beach ridges with their associated shallow groundwater lenses, so not even token supplies of freshwater are available from the ground-water sources. Thus, the saline ground-water problem has necessarily forced the city to construct a series of large surface-water storage facilities for its dry-season supply.

The storage facilities at Gò Công include four huge rectangular basins, each about a hundred metres on a side and with walls of compacted clay built up about $2 \mathrm{~m}$ high. During the wet season as nearby streams become filled with freshwater, the basins are pumped full of surface water. This storage is further supplemented by precipitation falling directly into the basins. For use the water is pumped from the basins into a small treatment plant, where it is filtered, purified, and fed into the municipal distribution system.

\section{RAINWATER CISTERNS}

Before drilled wells became available in the delta, simpler methods were used to obtain drinking water in the saline areas. One method commonly employed was the rainwater cistern which for a household supply might consist of one or two 50-gallon oil drums. For a hamlet or village, a large concrete cistern was commonly constructed. The rainwater was collected by gutters attached to roofs of houses and buildings and subsequently stored in the cistern for consumption in the dry season. In addition, water drawn from shallow wells, streams, and ponds, which temporarily may contain freshwater in the wet season, was also used to fill the cistern.

At Ba Tri in Tỉnh Kiên Hòa, for example, where sources of freshwater are particularly critical from November until May, the village has a concrete community cistern of about $200-\mathrm{m}^{3}$ capacity which serves a population of about 5,000 . With careful rationing this storage lasts for about 2 months during the dry season. Even so, as one village elder has explained, "Drinking water in the dry season is distributed as though it were medicine."

\section{DUG WELLS AND PITS}

Typically, dug wells in the delta are seldom more than $3 \mathrm{~m}$ deep. They are commonly curbed with concrete rings, usually $1 \mathrm{~m}$ in diameter and $1 \mathrm{~m}$ long. The rings are sunk under their own weight as sand is dug out of the center of each ring. To extract the water, a 
bucket fashioned from a 20-litre (5-gallon) square kerosene can is often used.

Dug wells usually tap the shallow lenses of fresh ground water lying beneath the dune and beach ridges of the delta. At Phú Vinh (Tra Vinh), for example, such freshwater lenses occur in a series of ridges about a hundred metres wide and several kilometres long. To tap this water a small pit can be formed by digging down a few metres to the water table or alternatively a shallow well with concrete curbing can be constructed. The water is sold from door to door by vendors at prices varying between 5 to 20 U.S. cents, according to demand, for two 20-litre containers. At the end of the dry season the price has been known to reach a high of $\$ 2.00$ per cubic metre of freshwater.

\section{DRILLED WELLS}

In the outer fringe of the delta some success has been achieved in obtaining freshwater from deep drilled wells. Initially, the first successful drilled wells were put down in the early 1930's by an affiliate of Layne Wells International. Staffed by French technicians and drillers, the affiliate, Hydraulique Asia, drilled several successful wells at Vinh Lo'i (Bac Lieu) and Quan Long (Ca Mau) in 1931-33. Since that time the company has put down numerous other production wells and test holes, chiefly in the northern part of the delta.

The GVN with the technical assistance of the U.S. International Cooperation Administration (US ICA), and later US AID, began extensive drilling operations in the delta about 1958. The first wells drilled were only about $100 \mathrm{~m}$ deep. During the 1960 's, however, as drilling capabilities improved wells as deep as $460 \mathrm{~m}$ were successfully completed. Since the early 1960 's more than 200 drilled wells ranging from 90 to $568 \mathrm{~m}$ deep have been put down for water supply in various parts of the delta.

\section{GEOLOGIC SETTING OF THE MEKONG DELTA F EGION}

The rocks of the Mekong Delta region range from Precambrian to Holocene age. The oldest known rocks of the region are those of the Kontum massif in central South Vietnam. This massif includes granite, gneiss, quartzite, and other crystalline rocks considered to be of Precambrian to early Paleozoic age. During the Paleozoic, areas north and south of this massif were downwarped and a thick series of limestone, sandstone and shale of Ordovician to Carboniferous age accumulated in the depressed areas.

In late Carboniferous time the older Paleozoic sedimentary rocks were metamorphosed, deformed, and uplifted during the mountain- 
building episode of the Hercynian orogeny. The Southern Annamese massif, which began to develop during this episode, later became part of the more extensive Indochinese Complex, which includes most of the present mountainous areas of South Vietnam, northern Cambodia, southern Laos and the fringes of the Khorat Plateau (lat $16^{\circ} \mathrm{N}$ and $103^{\circ} \mathrm{E}$ ) in eastern Thailand. Also during the Hercynian orogeny large granite plutons with associated dacite dikes invaded the older Paleozoic sedimentary rocks. During and following the Hercynian orogeny major volcanic activity is recorded in andesite flows which crop out in the Southern Annamese massif just north of the Mekong delta and in rhyolite and dacite flows which form resistant hills both in South Vietnam and southern Cambodia. In South Vietnam hills of rhyolite and dacite as well as of Hercynian granite are aligned in a northwest trend from Vưng Tàu, to Nui Bà Den (Black Virgin Mountain) near Tây Ninh. This same trend continues in Cambodia in rhyolite and dacite hills, which rise above the deltaic alluvium north of Phnom Penh. The trend coincides with that of the tectonic trough in which the alluvial complex of the Mekong Delta was later deposited.

During late Paleozoic (Permian) time as much as $450 \mathrm{~m}$ of fossiliferous limestone with some sandstone and shale was deposited in southern Cambodia. These rocks are exposed locally in small limestone hills in the delta region.

Late in Permian time deposition of sediments, largely interbedded continental sandstone, shale, siltstone and conglomerate, began in subsiding basins located in northern Cambodia, eastern Thailand, southern Laos, and the fringe of South Vietnam. This deposition continued through the Mesozoic era and into Eocene time. Locally, where swampy conditions prevailed, coal deposits were formed. In western Laos and eastern Thailand thick evaoprites including rock salt and gypsum also were formed. These rocks in Thailand are known as the Khorat Group and in Cambodia, Laos, and Vietnam as the Indosinias Formation.

During late Mesozoic time the Khorat and Indosinias rocks were uplifted, folded, and invaded by granite plutons, both in Cambodia and South Vietnam. During this episode a large northwest trending granite pluton was emplaced in the Chuŏr Phnum Krâvanh (Cardoman Mountain Range) of Cambodia, whose southern outliers from the Seven Mountains in Tỉnh Châu Đố, South Vietnam.

The northwest-trending tectonic trough, now filled with the Quaternary alluvial complex of the Mekong Delta, began to subside in late Tertiary time, probably along lines of crustal weakness that had developed in the Hercynian orogeny. During Plio-Pleistocene time the Old Alluvium was deposited by the Mekong and its tributaries in a vast deltaic fill which extended laterally to approximately the position 
of the present 80-m topographic contour (plate 2) along the bedrock margins and also seaward of the present coast line. This fill attained a thickness of $600 \mathrm{~m}$ or more along the axis of the trough but thinned to a featheredge along the bedrock margins. Concurrent with the early stages of the alluviation, local basaltic eruptions in lava flows and small volcanoes occurred along the northeastern and southwestern margins of the trough, both in Cambodia and in South Vietnam. Along both margins, the Old Alluvium is in places interbedded with and in part overlain by basalt flows, which are locally in South Vietnam as much as $\mathbf{1 0 0} \mathrm{m}$ thick. Basalt flows are also interbedded with sand and gravel beds of the Old Alluvium near Phnom Penh and in Khêt Takêv(Tekeo), Cambodia along the southwest margin of the trough.

Gentle downwarping along the axis of the delta and some uplift of the Old Alluvium along the northeast margin and probably also along the southwest margin has occurred as the trough has subsided and the locus of later Holocene deltaic alluviation (Holocene Alluvium) has shifted toward the south and southwest. The Old Alluvium in the area extending northwest of Saigon now strikes about N. $65^{\circ} \mathrm{W}$. and dips very gently at $1 / 2^{\circ}$ or less to the southwest. The elevations of the basal contacts of basalt flows overlying Old Alluvium now range from 20 to 30 m near Châmkar Kausu Chŭb (Chup), Khêt Kâmpóng Cham, Cambodia to about $80 \mathrm{~m}$ above sea level near Lộc Ninh, An Lôc (Hon Quan), and Xuân Lộc in South Vietnam. Locally, volcanic necks, presumably vents of once active volcanoes, rise to elevations of $200 \mathrm{~m}$ above sea level.

Northwest of Saigon the Old Alluvium (plate 2) underlies a gently undulating terrain ranging from 10 to $80 \mathrm{~m}$ above sea level. Characteristically, this terrain is capped by a crust of residual laterite or ironstone which may extend downward from the surface to depths of a few metres to as much as $10 \mathrm{~m}$. Beneath the surficial crust in the outcrop area, the Old Alluvium is unconsolidated to semiconsolidated coarse-grained sand and gravel interlensed with silt and clay and occasional layers of laterite. Downdip (southwest), however, the Old Alluvium becomes generally finer textured. The thickness of the Old Alluvium in the outcrop belt northwest of Saigon in South Vietnam ranges from a featheredge to about $135 \mathrm{~m}$. Downdip (southwest), however, beneath the Holocene cover the thickness of Old Alluvium increases to $400 \mathrm{~m}$ or more. One exploratory well at Phú Vinh, for example, penetrated more than $\mathbf{4 5 0} \mathrm{m}$ of Old Alluvium.

In the lower delta, the Holocene Alluvium deposited by the modern Mekong, the Sông Hâu Giang and their distributaries covers the Old Alluvium. Holocene Alluvium, consisting largely of unconsolidated silt and clay with some lenses of sand, blankets virtually all of the delta 
below an elevation of $10 \mathrm{~m}$ above sea level. The thickness of Holocene Alluvium in the apical sector of the delta in Cambodia and as far downstream as the Cambodian-Vietnamese border is generally less than $25 \mathrm{~m}$. Along the seaward margin of the delta, however, the Holocene Alluvium thickens to more than $100 \mathrm{~m}$ (plate 2). The Holocene Alluvium differs from the Old Alluvium in having a generally finer texture, almost no laterite, and a relative abundance of shell and lignite layers. Both the Holocene and the bulk of the Old Alluvium are considered to be of Quaternary age.

The bedrock beneath the alluvial fill of the delta includes a varied array of igneous, metamorphic, and consolidated sedimentary rocks. Only a few drilled wells, however, have reached the bedrock floor beneath the deltaic alluvium. Near Saigon the bedrock commonly encountered by drilled wells is either igneous dacite or red, green, and dark-gray consolidated siltstone and shale of the Indosinian Formation. In Saigon bedrock commonly lies at a depth of about $200 \mathrm{~m}$ beneath the deltaic alluvium, and at Gò Công, Indosinias shale was reached by the drill at $440 \mathrm{~m}$. On the other hand, at Phu Vinh, which is located near the central axis of the Mekong Delta, an exploratory well reached a depth of $568 \mathrm{~m}$ in Old Alluvium without encountering any consolidated bedrock, and at Bai Xàu in Tînh Ba Xuyên another well bottomed at $463 \mathrm{~m}$ in Old Alluvium. In the Seven Mountains area the bedrock commonly encountered is granite and near Hà Tiên, limestone. In these areas the alluvial fill above bedrock is commonly less than $100 \mathrm{~m}$ thick.

The pre-Quaternary consolidated rocks beneath and bordering the delta have appreciable but relatively small water-yielding potential to wells as compared to the alluvial deposits of the delta itself. A few wells in Tînh Châu Đốc have been put down to tap water in consolidated rocks. Individually, these yield no more than about 1.0 to $1.5 \mathrm{l} / \mathrm{s}$ (litres per second). The water-bearing characteristics of the Holocene Alluvium and Old Alluvium of the Mekong Delta are described in more detail in following sections.

\section{GROUND WATER IN QUATERNARY ALLUVIUM OF THE MEKONG DELTA}

Both the Holocene Alluvium and Old Alluvium of the Mekong Delta, as well as the weathered porous surficial zone of bordering consolidated rocks, are saturated with ground water. The regional water table which marks the upper surface of saturation in the alluvial deposits and consolidated rocks is shown by contours referred to sea level on plate 2. As shown on this map the water table in most of the deltaic alluvial tracts is $30 \mathrm{~m}$ or less above sea level and in the Holocene area of the delta is less than $5 \mathrm{~m}$ above sea level. 
HOLOCENE ALLUVIUM

The Holocene Alluvium in most of the Mekong Delta contains relatively poor aquifers, largely because of the fine texture of the deposits. Also nonpotable brackish or salty ground water is widely present in the Vietnamese sector of the delta. For example, in the Ca Mau Peninsula which is part of the trans-Sông Hậu Giang area, virtually all the 50 wells for which records are available have penetrated clay, silt, and fine sand, all containing brackish or saline water, to a depth of 50 to $100 \mathrm{~m}$, the full thickness of the Holocene Alluvium.

Even in the inland sector of the delta in Vietnam where the water in surface watercourses is fresh, the shallow aquifers in the Holocene Alluvium contain brackish or salty water. Two shallow jetted wells put down at Châu Phú, for example, both tapped brackish water in Holocene Alluvium containing $1,200 \mathrm{mg} / \mathrm{l}$ (milligrams per litre) of chloride. At Cân Tho', brackish-water aquifers extend from near the land surface down to depths of 120 to $170 \mathrm{~m}$ before a fresh-water aquifer is found in the Old Alluvium. In this area the surface flow in the Sông Hậu Giang is fresh the year around. Also at Vinh Long, about $30 \mathrm{~km}$ northeast of Cân Tho' on a freshwater distributary of the Mekong, saltwater aquifers occur from near the land surface down to a depth of $256 \mathrm{~m}$. Here the entire thickness of the Holocene Alluvium plus the upper part of the Old Alluvium contains salty water. Brackish ground water thus appears to prevail in the Holocene Alluvium as far inland as the Cambodian border. Nominally fresh water is reported, however, in shallow wells tapping the Holocene Alluvium of Khêts Prey Vêng, Takêv, and Svay Riĕng lying in the apical sector of the Mekong Delta in Cambodia. Thus, a zone of transition, as yet poorly defined, between fresh and brackish ground water apparently occurs in the Holocene Alluvium of the delta along a line somewhat inland from the Cambodian-Vietnamese border.

The available evidence seems to indicate that freshwater heads as they presently exist in the Holocene aquifers of Cambodia, are too low to flush out the brackish or salty water downgradient in Vietnam. The brackish or salty water is presumably connate and was included with the Holocene Alluvium when it was originally deposited. Also it appears that the freshwater in the rivers is poorly connected hydraulically with the Holocene aquifers of Vietnam, possibly because of relatively impermeable clay seals in the stream channels.

Aside from a saltwater problem, the Holocene Alluvium in the Đông Tháp Mu'o'i contains water that is locally and occasionally toxic. The Đông Tháp Mu'o'i, a large infertile wasteland, lies north of the Mekong River and south of the Parrots Beak of Cambodia. The area seasonally undergoes repeated flooding and drying, leaving a soil residue high in aluminum and magnesium sulphate. As a result of this process the shallow ground water also is high in aluminum sulphate (alum) and 
with an acid pH and high iron content. During 1964-66, W. C. Rasmussen carried out an intensive survey of water quality of $137 \mathrm{dug}$ wells in Tính Kiên Tu'o'ng in the Đông Tháp Mu'o'i. The survey showed that the average well was $1.3 \mathrm{~m}$ deep and that the quality of water in the wells deteriorated from northwest to southeast across the tinh. The mean content of aluminum and magnesium, for example, increased from 43 to $143 \mathrm{mg} /$; sulfates from 38 to $272 \mathrm{mg} /$; hardness from 82 to $251 \mathrm{mg} /$; iron from 1.5 to $3.1 \mathrm{mg} /$, and $\mathrm{pH}$ from 6.8 to 6.0 from northwest to southeast.

Alum-bearing waters are also reported to occur in a few dug wells tapping Holocene Alluvium in Tỉnh Châu Đôc, south of the Mekong. The water is described locally as "sour," but nevertheless is considered to be potable during the rainy season. From January to June, however, the water becomes more turbid, contains much alum and therefore is toxic for drinking.

SHALLOW FRESHWATER IN

ANCIENT BEACH AND DUNE RIDGES

Freshwater in the Holocene Alluvium of Vietnam is generally limited to shallow lenses contained locally in ancient beach and dune ridges in the delta. These ridges lie near former coastlines, where beach and dune complexes once existed. These complexes became stranded as the Mekong and its distributaries extended the delta seaward. The ridges are composed largely of wind-worked fine- to medium-grained sand that attain maximum elevations of 5 to $8 \mathrm{~m}$ above mean sea level. Because they form high ground, the axes of these ridges tend to be the sites of the main roads and settlements. Typically, the ridges are several kilometers long, about a hundred metres wide, and 3 to $5 \mathrm{~m}$ high. Locally they are called "giong" and resemble the "cheniers" of the Mississippi River delta in Louisiana. Freshwater accumulates underground in such ridges during the rainy season to form local shallow ground-water bodies generally conforming to the shapes of the ridges.

In two areas near $\mathrm{Ba}$ Tri and Phú Vinh studied by the writer, shallow ground-water bodies furnish important sources of water supply throughout the year. Near $\mathrm{Ba}$ Tri, where several beach ridges are present, only the highest ridges contain reserves of freshwater throughout the dry season. One ridge in particular, about $7 \mathrm{~km}$ southwest of $\mathrm{Ba}$ Tri and only 2 or $3 \mathrm{~km}$ from the sea, attains a height of $5 \mathrm{~m}$ and appears to contain the thickest and most substantial body of fresh ground water in the area (fig. 2). Dug wells on this ridge are only 2 to 3 $\mathrm{m}$ deep with water levels 0.5 to $1.5 \mathrm{~m}$ below land surface in the early part of the dry season. Several of these wells sampled in December 1968 contained water with $30 \mathrm{mg} / \mathrm{l}$ of chloride. In contrast, seven other dug wells sampled at the same time along similar but lower ridges 


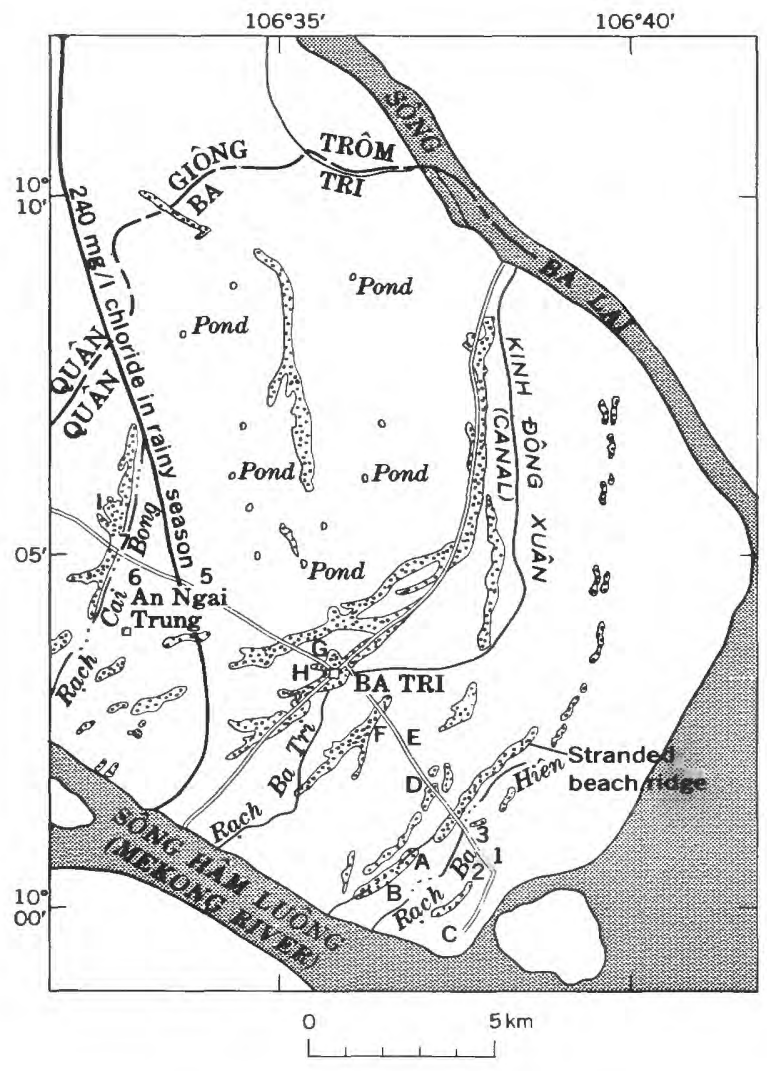

\section{EXPLANATION}

6

Surface-water sample

H

Dug well sample

\section{EXPLANATION}

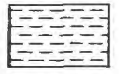

Clay

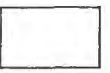

Sand and silt

(Holocene Alluvium)

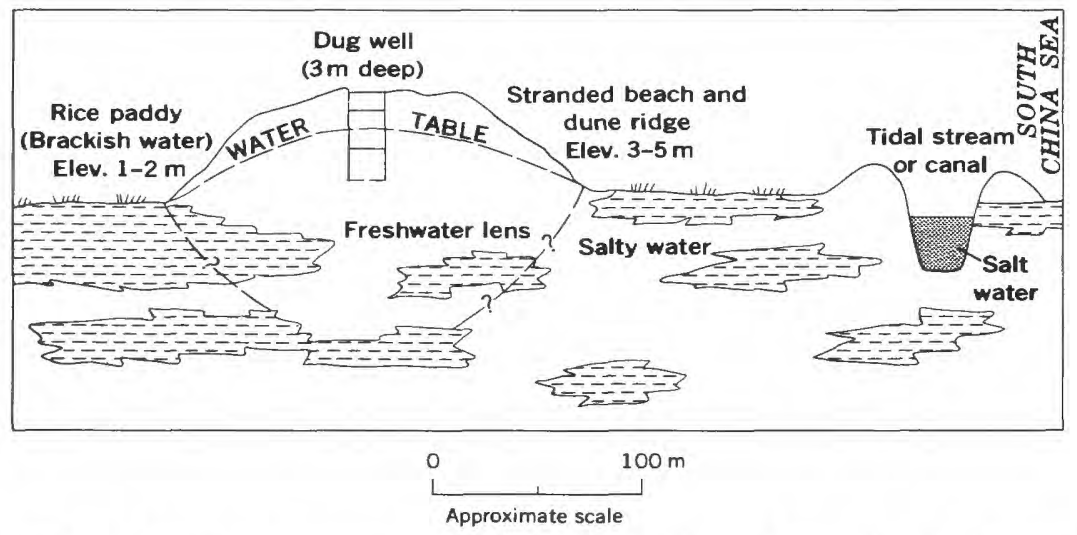

Figure 2. - Map and cross section of stranded beach ridges and ground-water lenses at Ba Tri.

near $\mathrm{Ba}$ Tri contained water with chloride concentrations ranging from 60 to $3,000 \mathrm{mg} /$. Also, seven surface-water samples collected from canals, rivers, and ponds near Ba Tri contained from 240 to 5,200 
$\mathrm{mg} / \mathrm{l}$ of chloride, with only three of these considered potable. As the dry season progresses the water in all the dug wells save those in the highest ridges turns salty. Moreover, deep exploratory drilling near $\mathrm{Ba}$ Tri by the GVN/US AID teams during 1969-70 failed to reveal any other freshwater aquifers down to a depth of $318 \mathrm{~m}$.

Shallow fresh ground-water bodies also exist in ancient beach and dune ridges south of the Mekong near Phú Vinh. Here deep test drilling, which was first attempted in 1931, has failed to reveal any indications of deep-lying freshwater aquifers. Recent test wells put down in the late 1960's by GVN/US AID teams, reached a depth of $568 \mathrm{~m}$ in the Old Alluvium with no indications of freshwater aquifers down to this depth. The freshest zone encountered lies at the base of the Holocene Alluvium only 50 to $75 \mathrm{~m}$ below land surface. The chloride content of the water in this zone was $800 \mathrm{mg} /$ in 1970 . The canals and streams in the Phú Vinh area contain freshwater almost 8 months of the year, but from about January until June the water is brackish or salty. During this dry period water for drinking is obtained from shallow freshwater bodies a few metres thick in unconsolidated sand of ancient beach and dune ridges. These ridges are from 3 to $5 \mathrm{~m}$ high, about a hundred metres wide and several kilometres or more long. The water is tapped by dug wells, but at Phú Vinh, more commonly, large pits are excavated into the saturated freshwater sand to form a pond. As Phú Vinh does not have a central treatment plant or distribution system, the water is sold from house to house by vendors. Although the water sometimes contains as much as $500 \mathrm{mg} / \mathrm{lchloride,} \mathrm{it} \mathrm{is} \mathrm{still}$ considered potable by the GVN standards.

\section{OLD ALLUVIUM}

Aquifers in the Old Alluvium are the principal sources of freshwater supply in the outer (seaward) part of the Mekong Delta and also to a large extent in the inner (inland) part of the delta. In places in Vietnam, however, the aquifers in the Old Alluvium also contain brackish or salty water. The approximate depths below land surface to the top of freshwater aquifers in the Old Alluvium of Vietnam in those parts of the delta which have been explored in some detail by test drilling are shown by contours on plate 1 .

\section{AREA SOUTHWEST OF THE SONG HẠU GIANG \\ INCLUDING THE CA MAU PENINSULA}

BAC LIEU 100-METRE AQUIFER

The first discovery of a deep-lying aquifer, which generally contains freshwater in the trans-Song Hâu Giang area was made by the French drilling company, Hydraulique Asia, an affiliate of La:ne Wells International, in 1931. The discovery well was put down at Quan 
Long in Tỉnh an Xuyên to a depth of $197 \mathrm{~m}$ and was tested with a screen set between 154 and $166 \mathrm{~m}$. With this setting the water level rose to land surface. By pumping, the well produced $21 \mathrm{l} / \mathrm{s}$ with $19 \mathrm{~m}$ drawdown. Since that time and through 1970 more than 50 wells have been put down, chiefly by GVN/US AID drilling teams, to tap the aquifer, known locally as the Bac Lieu 100-metre aquifer. Drilling results to date (1970) indicate that this aquifer extends under most of An Xuyên, Ba Xuyên, Bạc Liêu, and Chu'o'ng Thên Tỉnh. The top of the aquifer in this area lies at depths ranging between 60 and $120 \mathrm{~m}$ below land surface with a thickness ranging from about 25 to $50 \mathrm{~m}$ (plate $3 A$ ). The confining layer is clay and silt in the basal part of the Holocene Alluvium. The aquifer in Tinh Bac Liêu is chiefly gravelly sand but grades inland into a fine sand in Tỉnh Chu'o'ng Thị̂n. Although some of the wells tapping the 100-metre aquifer along the seaward margin of the delta flow naturally by artesian pressure, most are subartesian. Pressure heads generally range from $0.4 \mathrm{~m}$ above to $2.00 \mathrm{~m}$ below land surface.

Because of lack of pertinent well data, the recharge area for the fresh 100-metre aquifer of Vietnam has not been clearly established. One postulated recharge area is the apical sector of the delta in Cambodia where the surface water and shallow ground water of the Holocene Alluvium are perennially fresh. This area corresponds to a zone which undergoes seasonal freshwater flooding from the Mekong. In effect, the fresh surface water would infiltrate down through the Holocene Alluvium into the Old Alluvium.

The yields of wells tapping the 100-metre aquifer vary with type of well construction and aquifer permeabilities. Average yields for rotary drilled wells, for example, with 6- or 8-inch diameter screens, is about $19 \mathrm{l} / \mathrm{s}$, and specific capacities average $0.83 \mathrm{ls}^{-1} \mathrm{~m}^{-1}$ (litres per second per metre of drawdown). On the other hand, the average yield for jetted wells with 4 -inch diameter screens is usually less than $7 \mathrm{l} / \mathrm{s}$. The highest yields are obtained from the aquifer in Tính Bạc Liêu and Tính An Xuyên.

Saltwater contamination as a result of ground-water withdrawals, at least until the present (1970), has not been a general problem in the 100-metre aquifer, although some individual wells which initially produced freshwater, have "salted out" because of intensive pumping, faulty well construction, or a combination of both. Nevertheless, in all the four provinces thus far explored, local occurrences of in situ high chloride water have been observed in the aquifer. At Vi Thanh (Duc Long) (plate $3 B$ ) in Tính Chu'o'ng Thiẹn, chloride concentrations decrease with depth in the aquifer from $780 \mathrm{mg} / \mathrm{l}$ at $80 \mathrm{~m}$ to $270 \mathrm{mg} / \mathrm{l}$ at $124 \mathrm{~m}$. On the other hand, at Âp Giong Có in Tinh Ba Xuyên the salinity increases with depth. Here the aquifer has salty water at depths of $109 \mathrm{~m}$ and $150 \mathrm{~m}$ and freshwater at a depth of $60 \mathrm{~m}$. 
In Tỉnh Bạc Liêu some seasonal variation in chloride content of water in the 100-metre aquifer has been observed, that is, low chlorides occur in the rainy season when the water table is high and high chlorides occur in the dry season when the water table is low. For example, at Vĩnh Lo'i (Bac Lieu) in Tỉnh Bạc Liê a small-diameter jetted well showed a chloride fluctuation ranging from $14 \mathrm{mg} / \mathrm{in}$ the rainy season to $630 \mathrm{mg} / \mathrm{l}$ in the dry season. A tinh-by-tinh breakdown indicates that the average chloride values in 1970 were $595 \mathrm{mg} / \mathrm{f}$ for 15 samples in An Xuyên, $150 \mathrm{mg} / \mathrm{f}$ for 36 samples in Vînh Lo'i, $330 \mathrm{mg} / \mathrm{A}$ for 19 samples in Ba Xuyên and $500 \mathrm{mg} / \mathrm{l}$ for 12 samples in Chu'o'ng Thiẹn. It should be pointed out, however, that well waters that taste fresh are not often analyzed, consequently the actual salinity of the waters in the aquifer are probably lower than the averages tend to indicate.

BAI XAU 450-METRE AQUIFER

This aquifer was discovered almost by accident in 1967 by GVN/US AID drillers attempting to complete a well in a shallower aquifer at Bâ Xâu in Tính Ba Xuyên. In the depth range of the Bac Lieu 100metre aquifer the water was tested and was found to contain brackish water with $1,300 \mathrm{mg} / \mathrm{l}$ chloride. As this quality was unacceptable by GVN standards, the US AID advisers decided to continue drilling to the full capacity of the rig, if necessary, or to about $480 \mathrm{~m}$. At $250 \mathrm{~m}$ a clean sand was encountered but this too contained salty water with $5,900 \mathrm{mg} / \mathrm{l}$ chloride. Continuing downward after penetrating a confining clay at $440 \mathrm{~m}$, a sand and gravel zone was encountered by the drill between 440 and $460 \mathrm{~m}$. The well ended at a depth of $463 \mathrm{~m}$ in the Old Alluvium. The zone was tested and produced an artesian flow of $10 \mathrm{l} / \mathrm{s}$ of water containing only $130 \mathrm{mg} / \mathrm{l}$ of chloride. The temperature of the water was $40.5^{\circ} \mathrm{C}$.

To date (1970) the 450-metre aquifer has not been positively identified in other wells drilled in the delta. The only comparable aquifer is that 350 to $400 \mathrm{~m}$ deep at $M \widetilde{y}$ Tho about $75 \mathrm{~km}$ to the north and that 150 to $180 \mathrm{~m}$ deep at Cân Tho' about $50 \mathrm{~km}$ to the northwest. The aquifer at Cân Tho', however, is more likely to be correlative with the Bac Lieu 100-metre aquifer of the Ca Mau Peninsula (plate 3B).

INTERFLUVE BETWEEN THE

SONG HẬ GIANG AND THE MEKONG RIVER

Generally speaking there are few well data available for this area. Such data that exist generally indicate saltwater conditions in the subsurface to a depth of a few hundred meters. Test drilling in the interfluve began in 1931 at Phú Vinh in Tỉnh Vĩnh Bihn where the French drilling company, Hydraulique Asia, put down three boreholes 
to depths of 219,232 , and $282 \mathrm{~m}$ respectively. All these wells encountered water which is predominantly brackish or salty. The freshest water was found in an aquifer lying between depths of 72 to $87 \mathrm{~m}$. A well completed in this aquifer was later abandoned, however, in 1945, apparently because of saltwater contamination. GVN/US AID drilling teams have in recent years put down six additional deep test holes in the vicinity of Phú Vinh, the deepest of which was $568 \mathrm{~m}$. Again all these encountered brackish or salty water. Geologically, the strata from 80 to $100 \mathrm{~m}$ at Phú Vinh are probably equivalent to the Bac Lieu 100-metre aquifer of the Ca Mau Peninsula. Moreover, these gravelly sands can be traced northward along the coast of the delta to as far as Saigon (plate $3 C$ ). In contrast, however, to the freshwater occurrence in the Ca Mau Peninsula, the 100-metre aquifer in the interfluve north of the Sông Hậu Giang contains brackish water.

At Ba Tri in Tinh Kiên Hò (fig. 8) a well drilled to $318 \mathrm{~m}$ encountered salty water throughout its entire depth range. Also farther inland at Vinh Long (fig. 7), the ground water is brackish or salty from the land surface to a depth of $256 \mathrm{~m}$.

As indicated by the drilling thus far (1970) completed, the ground water, at least at depth, is mostly brackish or salty. The only known source of fresh ground water in the interfluve area is that in shallow lenses of freshwater contained in stranded beach ridges and dunes.

\section{AREA NORTH OF THE \\ SÔNG MY THO AND THE MEKONG RIVER}

In the area lying north of the Sông M $\widetilde{y}$ Tho including the outcrop area of the Old Alluvium, ground water has been extensively developed for rural and public water supply. The area includes Saigon municipality and Tinh Gia Định where many tens of wells have been put down by private drilling companies and also by GVN/US AID teams since 1958 .

The Saigon water supply at one time was entirely obtained from wells which produced as much as $160,000 \mathrm{~m}^{3} / \mathrm{d}$ (cubic metres per day) in 1960. The wells, drilled mostly by the Layne International Co., ranged from 30 to $200 \mathrm{~m}$ deep and had reported individual yields of as much as $95 \mathrm{l} / \mathrm{s}$. The average specific capacity of the Saigon wells was 4 $1 \mathbf{s}^{-1} \mathbf{m}^{-1}$.

\section{SAIGON TRI-PARTITE SANDS}

In the Saigon area, aquifers in the Old Alluvium are known as the Saigon Tri-Partite sands, although their identification as three distinct aquifers from well to well is often doubtful. The upper zone has undergone the most intensive development in the vicinity of Saigon. West and southwest of Saigon, however, the upper zone aquifer con- 
tains salty water and the middle zone is the principal source of water supply. Typical water-table fluctuations in the upper zone aquifer just north of Saigon are shown in figure 3.

From 1930 to 1960 , as pumpage increased to meet Saigon's needs, saltwater began to encroach into well fields tapping the upper zone aquifer. Consequently, it became necesary to revert to a surface-water source for the city supply. In 1964 construction was begun on a large surface-water treatment plant at Thu Dúc (Tu Doc), about $8 \mathrm{~km}$ north of Saigon to treat water from an intake on the Sông Đông Nai. By 1967 the plant was operational and in 1970 was delivering about $246,000 \mathrm{~m}^{3} / \mathrm{d}$ with a design capacity of about twice this amount. Existing well fields are still used occasionally as back-up supply in times of emergency or when regular treatment operations are interrupted.

The shallow aquifer in Kiến Phong, Kiên Tu'òng, Dinh Tu'òng, Long An, and Go Công Tỉnhs, which correlates with the upper zone aquifer of the Saigon Tri-Partite sands, almost everywhere contains brackish or salty water. Tongues of salty water are also present in the upper $100 \mathrm{~m}$ of alluvium as far inland as the Parrots Beak of Cambodia and in particular follow the main river channels of the Sông Vàm Cò Đông (east Vaico River) and Sông Vàm Cỏ Tây (west Vaico River) where the elevations are less than $2 \mathrm{~m}$ above sea level.
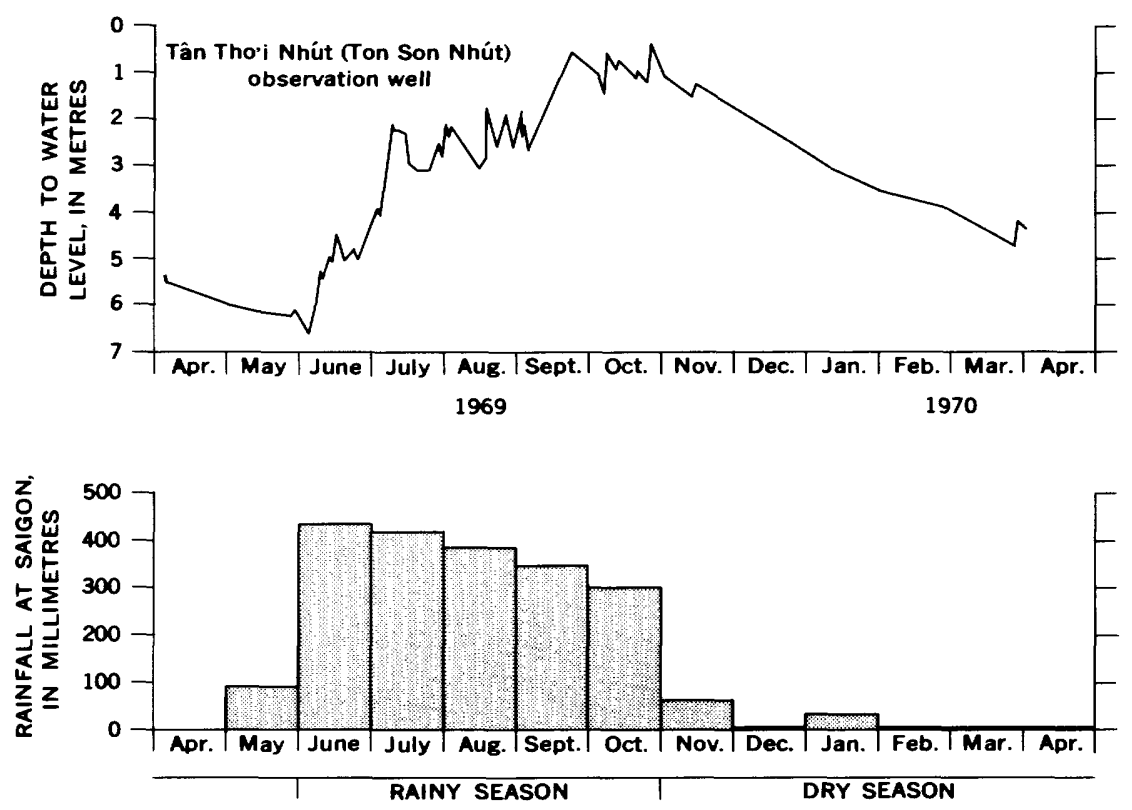

Figure 3. - Fluctuation of water levels in the Tân Tho'i Nhút (Ton Son Nhut) observation well, 1969-70, and rainfall at Saigon. 
The top of the middle zone freshwater aquifer lies at a depth of about 130 to $180 \mathrm{~m}$ for some $25 \mathrm{~km}$ southwest of Saigon (plate 3,D) and along Route 4. At Tru'o'ng Lu'o'ng near Mỹ Tho, however, the first freshwater occurs at a depth of about $350 \mathrm{~m}$. This condition suggests possible down-faulting or flexuring of the middle zone aquifer or possibly the presence of the equivalent of the lower zone aquifer of the Saigon Tri-Partite sands.

LONG AN 200-METRE AQUIFER

The Long An 200-metre aquifer derives its name from initial discovery of artesian water at that depth in Tân An village in Tính Long An. An abbreviated log of a Layne well drilled in 1958 indicates that interbedded clays, sands, and gravels containing saltwater extend to a depth of $143 \mathrm{~m}$; then a compact yellow clay, the principal confining bed, extends from 143 to $174 \mathrm{~m}$. A coarse yellow sand from 173 to 204 $\mathrm{m}$ forms the freshwater aquifer. At the time of completion the well was reported to flow a few litres per second naturally but would yield $28 \mathrm{l} / \mathrm{s}$ to pumping.

The static water levels of wells in the Long An aquifer are all very near to the land surface at five known sites in Tinh Long An, where intermittent flowing conditions occur. Casual observations in two wells at Rach Kien (plate $3, D$ ) indicate that the wells flow after the end of the rainy season (December 1969) but are nonflowing later in the dry season (February 1970). The static water level declined from about a $0.3 \mathrm{~m}$ above to about a $3.0 \mathrm{~m}$ below land surface during this period. The artesian flows from the aquifer are also very small. At Bình Phu'óc in Tỉnh Dinh Tu'o'ng, the observed artesian flow from a Layne well completed in the aquifer in November 1969 was only about $0.2 \mathrm{l} / \mathrm{s}$, although by pumping, the yield from the same well was easily increased to $22 \mathrm{l} / \mathrm{s}$.

The areal extent of the Long An 200-metre aquifer is somewhat limited. Saltwater zones lie above and below it and near the coast the aquifer itself contains saltwater. For example, at Go Cong the equivalent of the Long An 200-metre aquifer contains water with $6,000 \mathrm{mg} / 1$ of chloride (plate $3 \mathrm{C}$ ). Farther inland at Cân Du'o'c the aquifer extending below $210 \mathrm{~m}$, although not as salty, contains water with $1,500 \mathrm{mg} / \mathrm{l}$ of chloride.

The intake area for the Long An 200-metre aquifer is believed to correspond with the outcrop area of the Old Alluvium to the north, that is, in Bình Du'o'ng and Tây Ninh Tinhs. Rainfall percolates in the outcrop area of Old Alluvium along the footslopes of the Central Highlands and moves down gradient through sand and gravel beneath a confining layer. In the outcrop area of the Old Alluvium northwest of Saigon the general ground-water movement is in a southwest direction (plate 1). 
Other than the common occurrence of high chlorides and iron, the ground-water quality in the Long An 200-metre aquifer is rated as satisfactory by local standards. Iron-bearing ground water, however, has been observed at Nha Bè with concentrations of as much as 200 mg/, usually associated with a chloride content of more than 1,000 $\mathrm{mg} /$. Elsewhere, iron in the potable ground waters, while not so concentrated, commonly attains concentrations of 5 to $10 \mathrm{mg} /$. For example, in a 271-m well at Bên Lúc where the chloride content is about $600 \mathrm{mg} /$, the iron content ranges from 4 to $37 \mathrm{mg} / \mathrm{l}$. Primarily as a result of high iron content the well was abandoned. The $\mathrm{pH}$ levels in this water were in the range of 5.5 to 6.9 , on the acid side.

High-iron waters have also been found in the recently (1970) completed wells put down by Asia Wells Co. under contract with US AID. The wells from 140 to $215 \mathrm{~m}$ deep are located in five villages of Tinh Long An. The dissolved iron concentration in the waters from these wells ranged from a low of $0.43 \mathrm{mg} / \mathrm{to}$ a high of $1.39 \mathrm{mg} / \mathrm{l}$. Total iron concentrations ranged from 1.38 to $5.5 \mathrm{mg} /$. The range of chlorides in the wells was from 48 to $385 \mathrm{mg} /$, which is considered potable by GVN standards. The principal source of the iron in the ground water is believed to be ferruginous laterite layers interspersed through the Old Alluvium.

\section{AQUIFER IN OUTCROP AREA OF \\ OLD ALLUVIUM NORTHWEST OF SAIGON}

A belt of the Old Alluvium some 25 to $75 \mathrm{~km}$ wide and $150 \mathrm{~km}$ long extends northwest from Saigon through Tỉnh Biên Hòa, Tỉnh Bình Du'o'ng, and Tỉnh Tây Ninh in South Vietnam and Khêt Svay Riěng and Khêt Prey Vêng in Cambodia (fig. 2). The surface of this belt lies about 10 to $80 \mathrm{~m}$ above sea level in gently undulating terrain along the footslopes of the Central Highlands.

In Tỉnh Tây Ninh the several wells tap water-bearing zones in the Old Alluvium of this belt from $50 \mathrm{~m}$ down to a depth of $135 \mathrm{~m}$. The average yield among these wells is about $11.7 \mathrm{l} / \mathrm{s}$ with an average specific capacity of $0.66 \mathrm{ls}^{-1} \mathrm{~m}^{-1}$. In Tỉnh Binh Du'o'ng and Tình Bien Hò average well yields and specific capacities are $9.5 \mathrm{l} / \mathrm{s}$ and 1.1 $\mathrm{ls}^{-1} \mathrm{~m}^{-1}$ and $7.6 \mathrm{l} / \mathrm{s}$ and $0.5 \mathrm{ls}^{-1} \mathrm{~m}^{-1}$, respectively. Several wells in Khet Prey Vêng tap water in the Old Alluvium at depths ranging from 30 to $50 \mathrm{~m}$ and have average individual yields of $9.5 \mathrm{l} / \mathrm{s}$.

The static water levels recorded in drilled wells tapping the Old Alluvium of this belt range from $25 \mathrm{~m}$ below land surface to positive heads above land surface. Two wells near Tây Ninh reportedly each flow about $1.2 \mathrm{l} / \mathrm{s}$ after the rainy season. As shown on plate 1 the potentiometric surface of water in the Old Alluvium of this belt slopes southwest. 
Although salinity does not create a potability problem in the ground water of the Old Alluvium outcrop area, iron and low $\mathrm{pH}$ are locally troublesome. Low $\mathrm{pH}$ together with dissolved carbon dioxide results in water aggressive to mild steel, causing corrosion of wells and pumps in some parts of Biên Hòa and Bînh Du'o'ng Tìnhs.

\section{CONCLUSIONS}

The foregoing discussion of ground water in the Mekong Delta would seem to imply that at least one freshwater aquifer is usually available in almost all parts of the delta, but this, however, is not necessarily true. There are still large expanses of the delta, perhaps as much as one half of the total area, where ground-water conditions are largely unproven. In particular, these areas include the interfluve between the Sông Hậu Giang and Mekong River and the interior sector of the delta where salty ground water lies near the land surface, including the Đông Tháp Mu'o'i. Also in areas where freshwater aquifers have actually been proven, the well data are widely distributed and not comprehensive.

Many basic questions remain yet to be answered. Among these are the areal limits of the Bac Lieu 100-metre aquifer in the Ca Mau Peninsula and its extension inland beneath the fresh surface-water areas of the delta. Where does the recharge to the 100-metre aquifer originate? Why does the 100-metre aquifer apparently become saline north of the Sông Hậu Giang? Still other unsolved problems concern the 450-metre aquifer at Băi Xàu. What is its areal extent? Does it correlate with the 350-metre aquifer at M $\widehat{y}$ Tho? This in turn brings up the question of whether 350-metre aquifer at Mỹ Tho is continuous with the Long An 200-metre aquifer or is the equivalent of the lowermost Tri-Partite sand in Saigon. Also to be proven are the extensions of these aquifers into Cambodia and the location of probable recharge areas. These and numerous other questions remain to be answered before intensive development of any of these aquifers takes place in the delta.

Test-drilling programs should be implemented to help resolve some of these problems. In addition, observation wells should be set up to monitor water levels and salinities within each aquifer. A groundwater sampling program would help also to evaluate the threat, extent, and progression of saltwater intrusion and more local contamination of the aquifers.

In actual drilling of test wells more sophisticated types of logging such as conductivity, chloride and neutron logging would add to the already high capability of electric and gamma ray logging in helping to pinpoint freshwater zones in test wells. 
Data on the hydraulic properties of aquifers are also largely lacking in the delta. As more wells and test holes are drilled and aquifer tests are conducted, estimates can be made with respect to optimum spacing of wells and aquifer development. These investigations will eventually lead to computer model studies of aquifers and their related confining layers for the entire Mekong Delta.

With careful development and controlled management, it is estimated that freshwater aquifers eventually could provide approximately 80 percent of the existing needs for village and small municipal water supplies in the delta.

\section{REFERENCES}

Anderson, H. R. and others, 1968, Investigation for fresh water at Ba Tri, Kien Hoa Province, Vietnam: U.S. Agency for International Development manuscript report, 11 p., 2 figs.

Harned, D. W., Ramecker, M. H., Rasmussen, W. C., and Burgh, J. A., 1968, Water for Vietnam: The Military Engineer, no. 394, Mar.-Apr. 1968, p. 86-89.

Haworth, H. F., 1966, Review of well drilling activities in South Vietnam: U.S. Agency for International Development manuscript report, 7 p., 1 fig.

Michael, E. D., 1971, Use of ground water in developing the Mekong Delta, Republic of Viet Nam: Ground Water, vol. 9, no. 1, p. 20-24.

Pham, V. H., 1968, How to find fresh water for Ba Tri District, Xien Hoa Province, Vietnam: U.S. Agency for International Development manuscript report, 13 p., 4 figs., 1 appendix.

Rasmussen, W. C., and Bradford, G. M., 1977, Ground-water Resources of Cambodia: U.S. Geol. Survey Water Supply Paper 1608-P, 122 p.

Rasmussen, W. C., and Quynh, N. N., 1967, Magnitude of the ground-water resources of the Mekong Delta, Vietnam: U.S. Agency for International Development manuscript report, $2 \mathrm{p}$. 